\title{
Diminished vessel diameter as a possible factor in the decline of European ash (Fraxinus excelsior L.)
}

\author{
Mirela TULIK*, Katarzyna MARCISZEWSKA, Jacek ADAMCZYK \\ Warsaw University of Life Sciences - SGGW, Department of Forest Botany, Nowoursynowska 166 St., 02-787 Warsaw, Poland
}

(Received 15 June 2009; accepted 18 August 2009)

Keywords:

earlywood vessels /

hydraulic conductivity /

Fraxinus excelsior /

tree decline /

wood annual increments

Mots-clés :

vaisseaux du bois initial /

conductivité hydraulique /

Fraxinus excelsior /

dépérissement des arbres /

accroissements annuels du bois

\begin{abstract}
- The aim of this work was to examine the anatomy and functioning of secondary xylem in stems in relation to the decline of European ash (Fraxinus excelsior L.).

- We tested the hypothesis that declining trees show changes in the structure of wood, which result in impaired water transport.

- Anatomical analyses were carried out on wood samples (comprising all annual rings formed during the 30 years life of the analysed trees) collected at breast height from the main stem of healthy, weakened and dead ash trees. The width of annual wood increments, the diameter and density of earlywood vessels were measured and the theoretical hydraulic conductivity index through the secondary xylem calculated by application of Hagen-Poisseuille's formula.

- Anatomical characteristics changed both with the age of trees and in response to unfavorable factors. The largest vessels were observed in healthy trees, which implied that they had the highest hydraulic conductivity index, whereas trees considered to be in decline produce smaller vessels and hence had reduced conductivity.
\end{abstract}

Résumé - La diminution du diamètre des vaisseaux, un facteur possible du dépérissement de Fraxinus excelsior $\mathbf{L}$.

- Le but de ce travail était d'étudier l'anatomie et le fonctionnement du xylème secondaire dans le tronc en relation avec le dépérissement de Fraxinus excelsior L.

- Nous avons testé l'hypothèse selon laquelle les arbres dépérissants présentent des changements dans la structure du bois, qui se traduisent par un dysfonctionnement du transport de l'eau.

- Des analyses anatomiques ont été effectuées sur des échantillons de bois (comprenant tous les cernes formés au cours des 30 années de vie des arbres analysés) recueillis à hauteur de poitrine sur la tige principale d'arbres sains, affaiblis ou morts. La largeur des accroissements annuels du bois, le diamètre et la densité des vaisseaux du bois initial ont été mesurés, et un indice théorique de conductivité hydraulique du xylème secondaire a été calculé par l'application de la loi de Hagen-Poisseuille. - Les caractéristiques anatomiques ont changé à la fois avec l'âge des arbres et en réponse à des facteurs défavorables. Les vaisseaux les plus largers ont été observés chez les arbres sains, ce qui implique un indice de conductivité hydraulique élevé, tandis que les arbres considérés comme dépérissants ont produit des vaisseaux plus petits et avaient donc une conductivité réduite.

\section{INTRODUCTION}

There are two functionally and structurally distinct cell systems in secondary xylem of trees, both produced by the periclinal division of cambial cells (Larson, 1994). In ash trees, the first system consists of vertically oriented vessels, fibers and axial parenchyma cells; the second is oriented radially and is represented by homogeneous rays. The wood pattern of European ash (Fraxinus excelsior L.) is ring-porous

*Corresponding author: mirela.tulik@wl.sggw.pl with vessel diameters ranging between $250-350 \mu \mathrm{m}$ in earlywood (Jacquiot et al., 1973), decreasing to $50 \mu \mathrm{m}$ in latewood (Jacquiot et al., 1973). The large earlywood vessels contribute to the greater part of water flow throughout the shoot but, due to their large lumen diameter, the vessels are also vulnerable to embolisation induced by frost or other factors, biotic included (Cochard et al., 1997). Moreover, they are only functional in the year of their formation (Zimmerman and Brown, 1977). Ash is a ring-porous species, and the earlywood vessels' expansion and maturation start before budbreak (Atkinson and Denne, 1988), utilizing the past year's carbohydrate reserves. 
Table I. The characteristics of European ash (Fraxinus excelsior L.) trees selected for studies during sampling in 2008.

\begin{tabular}{|c|c|c|c|c|c|c|c|c|c|c|c|c|c|c|c|c|}
\hline \multirow[t]{3}{*}{ Class of health condition } & \multicolumn{4}{|c|}{ Defoliation $(\%)$} & \multicolumn{4}{|c|}{ Breast height age (years) } & \multicolumn{4}{|c|}{ Total height (m) } & \multicolumn{4}{|c|}{ Height of crown level (m) } \\
\hline & \multicolumn{3}{|c|}{ Tree No. } & \multirow{2}{*}{ mean } & \multicolumn{3}{|c|}{ Tree No. } & \multirow{2}{*}{ mean } & \multicolumn{3}{|c|}{ Tree No. } & \multirow{2}{*}{ mean } & \multicolumn{3}{|c|}{ Tree No. } & \multirow{2}{*}{ mean } \\
\hline & 1 & 2 & 3 & & 1 & 2 & 3 & & 1 & 2 & 3 & & 1 & 2 & 3 & \\
\hline Healthy & 25 & 25 & 20 & 23 & 33 & 34 & 30 & 32.3 & 21.0 & 21.0 & 21.0 & 21.0 & 9.3 & 11.0 & 11.5 & 10.6 \\
\hline Weakened & 95 & 90 & 90 & 92 & 31 & 31 & 32 & 31.3 & 17.0 & 18.0 & 17.5 & 17.5 & 10.0 & 10.0 & 6.0 & 8.7 \\
\hline Dead & \multicolumn{4}{|c|}{$\begin{array}{l}\text { Withered branches } \\
\text { without leaves }\end{array}$} & 34 & 31 & 30 & 31.6 & 21.0 & 17.0 & 20.5 & 19.5 & 12.2 & 9.7 & 11.4 & 11.1 \\
\hline
\end{tabular}

Cambial activity and subsequent phases of vessels differentiation are controlled by plant hormones, especially by polar auxin transport (Roberts et al., 1988; Zajączkowski et al., 1984).

To use a simple physical analogy, xylem vessels are long pipes with an almost circular cross-sectional area. Effectively, they are capillaries and thus a change in vessel diameter translates into a change in laminar flow in relation to the fourth power of the vessel radius (Tyree and Zimmermann, 2002). Therefore, even a small reduction of vessel diameter could result in a considerable decrease in efficiency of water transport.

Since the 1990's the progressive and little understood process of ash-tree decline (AD) has been noted (Kowalski and Łukomska, 2005; Lygis et al., 2005). Decline is observed in European countries and in North America where it concerns Fraxinus nigra (Ward et al., 2007) and Fraxinus velutina (Bricker and Stutz, 2004). Although the reasons for the decline are still unknown, observations suggest that biotic factors - pathogenic fungi, in particular - are responsible for this phenomenon. Bricker and Stutz (2004) detected in tissues of Fraxinus velutina a phytoplasma (bacteria without a cell wall) which causes slow growth and advancing decline of ash trees. Kowalski (2007) described a new fungus species, Chalara fraxinea, in declining European ash trees in Poland. Probably, there are numerous biotic and abiotic factors (water stress, poor soil conditions, climate impact) contributing to the decline by exerting an effect which exceeds the potential of the tree for adaptation. Margio et al. (2000), describing ecophysiological characteristics of the European ash, particularly focused on the mechanism of water status regulation, mentioning that: "the reduction of stomatal conductance, osmotic and elastic adjustment as adaptation mechanisms to unfavourable environmental conditions including soil water deficits". According to Köcher et al. (2009), Fraxinus excelsior exhibits a drought resistance strategy with high leaf conductance and $\mathrm{CO}_{2}$ assimilation level while xylem sap flux is stable under condition of water shortage.

The most common symptoms of the decline appear irrespective of age. However, trees at the age of about $20 \mathrm{y}$ seem to more sensitive to the impact of unfavorable environmental conditions than are older trees. The symptoms of ash-tree decline are typically growth reduction and crown dieback. The lack of apical dominance, bright chlorotic foliage and witches brooms are also observed, as well as the decay of the root systems, but these are likely to be advanced symptoms arising after the initial trigger of decline has been registered.
There is no detailed information in the literature about the structure and functioning of secondary xylem of declining ash. Therefore, we tested the hypothesis that the anatomy of secondary xylem is altered in trees in decline and, as a consequence, this induces changes in the hydraulic efficiency of the xylem. The hypothesis was upheld by measurements and calculations of: (i) the annual ring width of wood; (ii) density of earlywood vessels distribution; (iii) diameter of earlywood vessels; (iv) index of theoretical hydraulic conductivity according to Hagen-Poiseuille law.

\section{MATERIALS AND METHODS}

Disc samples of wood were taken in May 2008, at breast height $(b h=1.3 \mathrm{~m})$ from the main stem of nine European ash trees (Fraxinus excelsior L.) growing in the Ruchna Forest District, in central part of Poland. Ash was a dominant component of the stands within which the ash-decline process (AD) was observed. On the basis of the degree of defoliation, three classes of health were established for the trees. The first represented healthy trees, the second encompassed weakened trees with dieback symptoms, and the third consisted of dead trees. These last-mentioned trees had died in the year of the study. Characteristics of trees selected and harvested for investigation are given in Table I.

For light microscopic studies, one wood strip containing all annual increments was removed from one radial axis from each of the nine discs cut from stems. The samples were boiled for a few days in an equal-part's solution of glycerin, water and ethyl alcohol in order to soften the wood. Transverse sections, covering the full complement of annual growth rings, along one radial axis, were cut with a Carl Zeiss sliding microtome (Microm HM 440E) at a thickness of approximately $30 \mu \mathrm{m}$. The sections were transferred onto slides, fixed in glycerin, and mounted under a coverslip. For vessel diameter measurement, images were acquired with the aid of an Olympus system consisting of BX61 motorized microscope and Cell P image analysis software coupled to a digital color camera DP70, using bright-field optics and magnifications of $\times 20$ or $\times 100$. An Olympus SZX9 stereomicroscope system equipped with Olympus ColorView IIIu camera and GetIt image analysis software was used for wood photomicrography.

The widths of consecutive annual rings (in $\mu \mathrm{m}$ ), density of earlywood vessels (the number of earlywood vessels per $\mathrm{mm}^{2}$ in each measured annual ring area), and the diameter (in $\mu \mathrm{m}$ ) in the radial plane of at least twenty entire earlywood vessels in each annual ring were measured using the stored digital images. On the base of diameters measurements, the mean nonweighted diameter $(D)$ and hydraulically weighted diameter $\left(D_{s}\right)$ of vessels were calculated. The 
latter was computed using estimator defined by Sperry et al. (1994) as follows:

$$
D_{s}=\Sigma D^{5} / \Sigma D^{4} \text {. }
$$

Measurements were performed on a total of 270 growth increments and 6210 vessels. Conversions to $\mathrm{mm}$ were with an accuracy of $\pm 0.01 \mathrm{~mm}$. Data are presented for rings averaged over 5-y intervals (the youngest ring being produced in 2007) for three trees belonging to the three health groups. In all, the data covered the last thirty years of trees growth, corresponding to the calendar years from 1978 until 2007. The samples are thus matched for the year of ring formation but not necessarily for tree age or breast height age.

The theoretical annual hydraulic conductivity $(K)$ was estimated for entire rings following Hagen-Poisseuille's law and using the vessel diameter measurements from each tree and each annual ring. The hydraulic conductivity was estimated for the ring area comprising the measured vessels and then, based on the area ratio of this ring section to whole ring, conductivity was estimated for the entire ring. The entire annual ring area was calculated from the inner and outer radius. Averages were obtained for 5-y intervals for each health group of trees and a relative index, $I$, based on the maximal average conductivity of healthy trees, was assessed for the other groups.

The flow of water through a vessel can be compared to the flow through a smooth-walled capillary of circular cross section. In compliance with the Hagen-Poiseuille law, flow is proportional to the pressure gradient and hydraulic conductivity, and is formulated (Tyree and Zimmerman, 2002; Zajączkowski, 1996) according to the equation:

$$
\mathrm{d} V / \mathrm{d} t=\mathrm{d} P / \mathrm{d} l K_{\text {capillary }} \text { and } K_{\text {capillary }}=\pi r^{4} / 8 \eta
$$

where $\mathrm{d} V / \mathrm{d} t$ is the volume $(V)$ of liquid flowing through a capillary in time $(t), \mathrm{d} P / \mathrm{d} l$ concerns the gradient of pressure $(P)$ along a capillary of length $(l), K_{\text {capillary }}$ is the hydraulic conductivity, and $\eta$ is a viscosity coefficient. When many capillaries of different radii are present, as in the case of the vessels in a transverse section of stem, the Hagen-Poiseuille law is written as follows:

$$
\mathrm{d} V / \mathrm{d} t=\mathrm{d} P / \mathrm{d} l K_{i}=\mathrm{d} P / \mathrm{d} l \sum \pi r_{i}^{4} / 8 \eta .
$$

Leaf transpiration causes a pressure gradient along whole tree $(\mathrm{d} P / \mathrm{d} l)$. The resulting negative hydrostatic pressure is variable and depends on the height in stem, the time of day, and stomata state. Data concerning the hydrostatic pressure gradient were not available at the time of tree sampling. However, if we assume that the same gradient occurs in all three groups of trees and that $\eta$ is constant, then the flow of water depends mainly upon the radius of the water-conducting elements.

In line with the above, we calculated relative conductivity index, $I$, for each annual ring of healthy, weakened and dead trees and compared these, as a percentage of the maximal average conductivity of healthy trees, as follows:

$$
I=\Sigma \pi r_{i}^{4} / \Sigma \pi r_{j}^{4} n^{-1} 100 \%
$$

where $r_{i}$ is mean vessel radius of indexed ring, $r_{j}$ is mean radius of healthy trees vessels and $n$ is the number of healthy trees $(n=15)$ whose rings were averaged. Next, the annual indices of hydraulic conductivity expressed as a percentage of maximal conductivity, were averaged for groups of trees for each 5-y period.

Measurements were assessed using standard statistical tools. The data concerning width of wood annual increment, diameter of earlywood vessels and hydraulic conductivity were analyzed using Student's t test at the 0.02 or 0.05 significance level for comparison of means.

\section{RESULTS}

\subsection{The annual ring width}

Annual ring width of investigated trees ranged between minimal and maximal values of $0.24 \mathrm{~mm}$ and $9.32 \mathrm{~mm}$. The average ring width, calculated over the lifespan of healthy, weakened and dead trees amounts to $2.97 \mathrm{~mm} \mathrm{y}^{-1}(\mathrm{SE}=0.20)$, $2.96 \mathrm{~mm} \mathrm{y}^{-1}(\mathrm{SE}=0.24)$ and $2.78 \mathrm{~mm} \mathrm{y}^{-1}(\mathrm{SE}=0.14)$, respectively. There were no statistically significant differences between these values. When analyzed in 5-y intervals, stem radial growth revealed a very similar pattern for all groups of trees: ring width reached a maximal value after the first $15 \mathrm{y}$ analyzed in our study, and this was followed by a progressive decrease (Fig. 1). Maximal ring width was $5.42 \mathrm{~mm}$ in the case of healthy trees, had an intermediate value of $4.84 \mathrm{~mm}$ for weakened trees, and was at its lowest $(4.24 \mathrm{~mm})$ for dead trees. The lowest value of ring width during the last five years was confined to the group of weakened trees.

The early-to-latewood ratio within the annual wood increment was not measured in this work. However, the relation between the width of annual increment and ratio of early-tolatewood contribution could be seen clearly on microscopic images, irrespective of the health condition of trees: the narrower the increment, the lower the latewood contribution to the ring (Fig. 2).

\subsection{Density of earlywood vessel}

Initially the density of vessels amounted to 74, 67 and 47 vessels per $\mathrm{mm}^{2}$ of ring area for healthy, weakened and dead trees, respectively (Fig. 3). Afterwards all groups of trees proved to have very similar patterns of early vessel density, i.e. decreasing with age (Fig. 3). For weakened trees, the density dropped to the lowest level (3.37 vessels per square mm of ring area) at the end of recorded growth but it did not differ in statistically significant manner from the other two groups of trees, showing 6.62 and 8.85 vessels per $\mathrm{mm}^{2}$ of ring area for dead and healthy trees, respectively.

\subsection{Nonweighted and hydraulically weighted radial diameter of earlywood vessels}

All groups of trees had a similar pattern of changes in earlywood vessels diameters $\left(D, D_{s}\right)$ i.e. an increase of diameter with age (Figs. 4A, 4B). However, within the recorded growth period, mean early vessels radial diameters were significantly higher $(P=0.02)$ for the group of healthy trees over the whole lifetime. Initial nonweighted diameters $(D)$ were $0.15 \mathrm{~mm}$ in case of healthy trees, but reached only $0.12 \mathrm{~mm}$ for weakened and dead trees. The highest $D$ was recorded in healthy trees during the last $5 \mathrm{y}$ of their growth and amounted up to $0.24 \mathrm{~mm}$, whereas for weakened and dead trees it reached $0.20 \mathrm{~mm}$. In all cases, after a quick increase in vessel diameters $\left(D, D_{s}\right)$, there was a period with relatively small increments, 


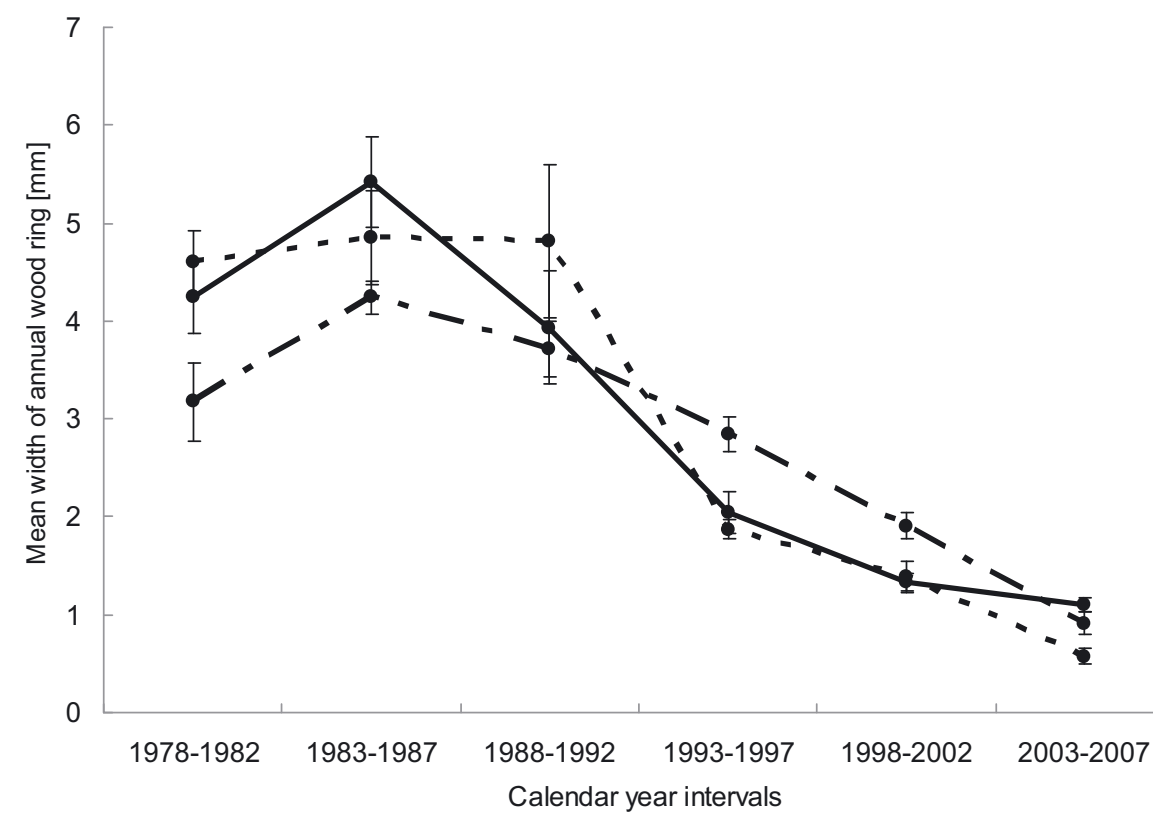

Figure 1. Annual ring width variation at breast height of European ash trees, representing different health conditions at time of sampling, over the calendar years 1978-2007. Ring width has been calculated as the mean for three trees belonging to the group of healthy (solid line), weakened (dashed line) or dead trees (dotted-dashed line), respectively, and for 5-y time intervals. Vertical bars denote standard errors.

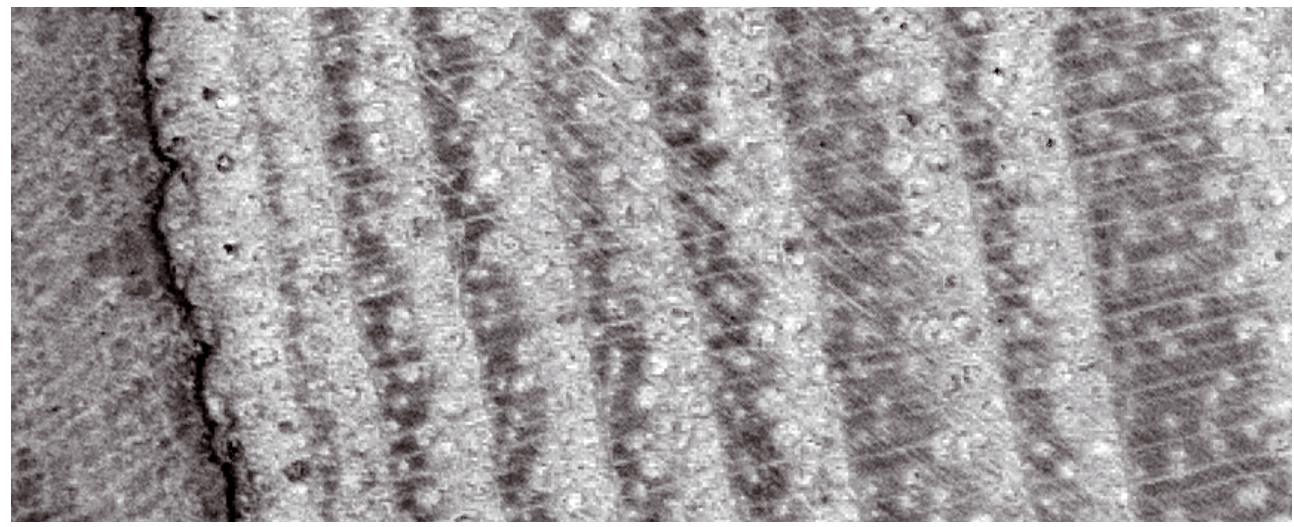

Figure 2. Transverse section of European ash stem wood at breast height. Image in reflected light, acquired at magnification $\times 8.3$ with an Olympus SZX9 stereomicroscope system equipped with Olympus ColorView IIIu camera and GetIt software. Close to the bark, a sequence of few annual rings comprising very narrow, average width and wide increments is present. On the photomicrograph, late wood is darker than earlywood. The abatement of latewood zone is intrinsic to the annual ring width decrease, while the earlywood area is almost unchanged.

reaching a plateau level before the last 5-y interval. Then, during the last $5 \mathrm{y}$ of growth, a decrease in vessels radial diameters occurred for weakened trees, whereas an increase was observed in the case of healthy trees. The mean weighted and nonweighted diameters stayed nearly steady in the dead trees. The curves of $D$ and $D_{s}$ are very similar but shifted on the $Y$-axis towards higher values in case of $D_{s}$.

\subsection{Hydraulic conductivity}

The theoretical water conductivity index (Fig. 5) showed a tree-age-related trend, similar to vessel diameter. Over the in- vestigated growth period, the group of healthy trees revealed much more efficient water conduction in comparison to the two other groups. Differences between the groups were statistically significant $(P=0.02)$ over the whole of the investigated period of growth. During the first $20 \mathrm{y}$, an increase of hydraulic conductivity index for all groups of trees was observed, but it was about two times higher in the case of healthy trees (Fig. 5) than in the other groups. Afterwards (from 1999 to 2003), the hydraulic conductivity index was maintained at a constant level in healthy trees. The group of dead trees continued the same trend, with conductance slightly increasing during the last five years of life. At this time, the hydraulic conductivity index of healthy trees reached a maximum value, 


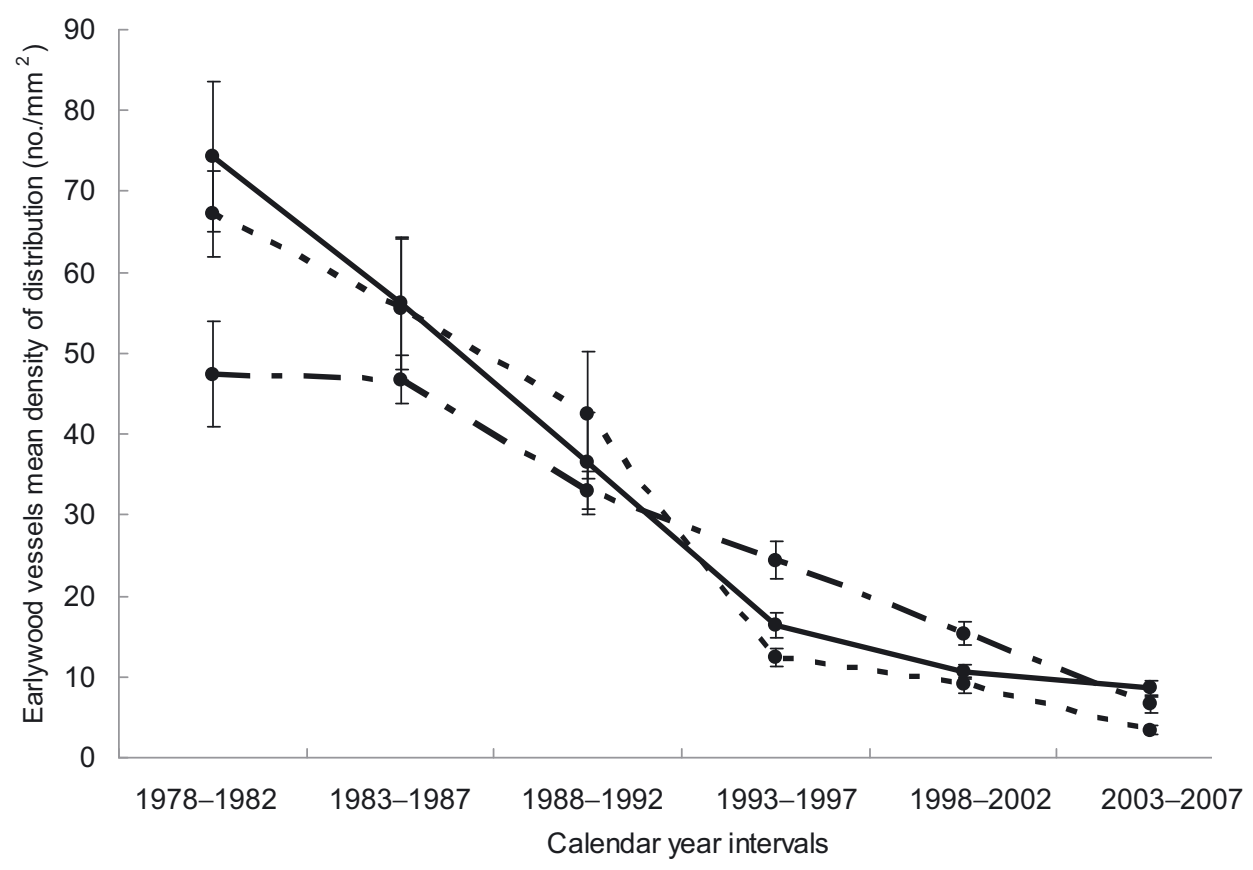

Figure 3. Variation in mean density of earlywood vessels distribution at breast height of European ash trees, representing different health conditions at time of sampling, over the calendar years 1978-2007. Density of vessels was defined as the number of earlywood vessels per $\mathrm{mm}^{2}$ of annual ring area and calculated as a mean for three trees representing the group of healthy (solid line), weakened (dashed line) or dead trees (dotted-dashed line), respectively, and for 5-y time intervals. Vertical bars denote standard errors.
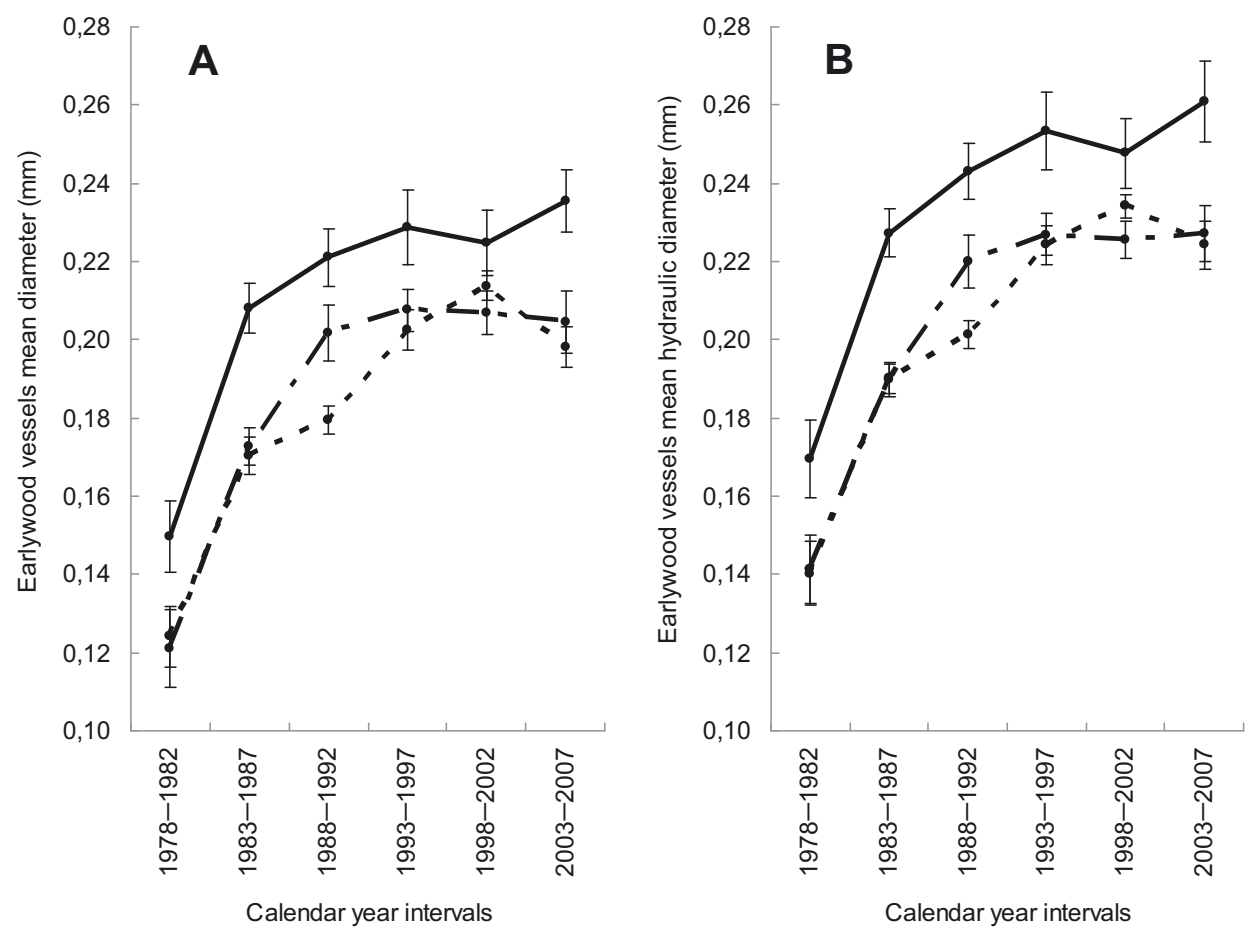

Figure 4. Variation in earlywood vessels mean diameters $\left(D, D_{s}\right)$ at breast height of European ash trees, representing different health conditions at time of sampling, over the calendar years 1978-2007. A - mean calculated for nonweighted data (mean diameter $D$ ), B - hydraulically weighted ones (mean hydraulic diameter $D_{s}$ ). Calculations are based on at least twenty vessels diameter measurements within each annual ring and records averaged for three trees representing the group of healthy (solid line), weakened (dashed line) or dead trees (dotted-dashed line), respectively, and for 5-y time intervals. Vertical bars denote standard errors. 


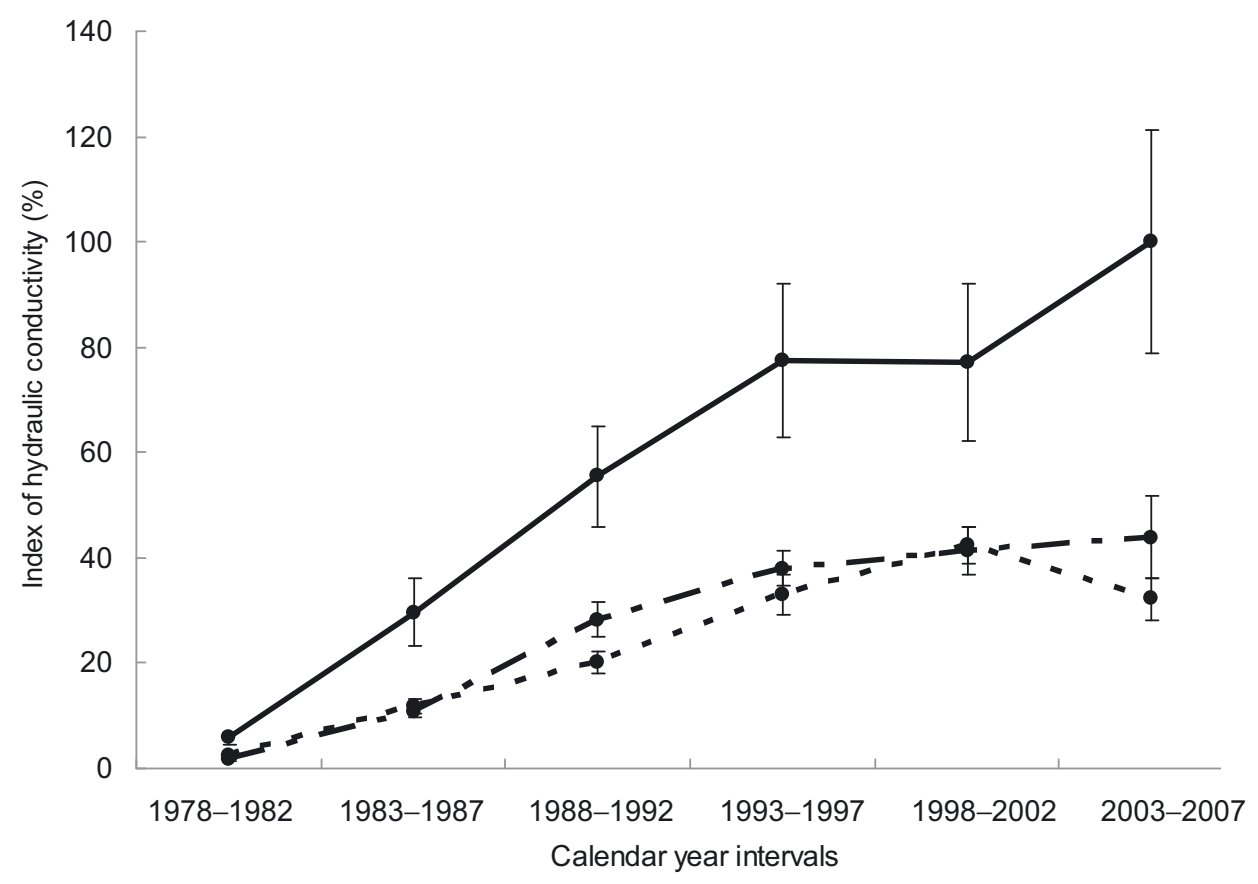

Figure 5. The index of theoretical hydraulic conductivity in secondary xylem at breast height of European ash trees, representing different health conditions at time of sampling, over the calendar years 1978-2007. This parameter was estimated from Hagen-Poiseuille equation for each annual increment and calculated as a percentage of maximal average conductivity of healthy trees. The indices were then averaged for 5-y time intervals and for the group of healthy trees (solid line), weakened (dashed line) and dead trees (dotted-dashed line), respectively. Vertical bars indicate standard errors.

which was approximately two times higher than those of the dead and weakened ashes. The hydraulic conductivity index of weakened trees also showed an increasing trend, like that described above for the two other groups, but was always lower (ranging between $23.8 \%$ and $42.28 \%$ ). In the last five years, it decreased suddenly, contrary to the other groups of studied trees. At this time, it was decreased by about $13 \%$ in comparison to the previous five years.

\section{DISCUSSION}

Generally, over the course of a tree's life, the widths of annual rings sampled at breast height are reported to show either a decreasing or leveling-off trend in the radial direction. An exception is the juvenile phase of growth and formation of core wood (Larson et al., 2001; Zobel and Sprague, 1998). This was also observed within the investigated population of ash trees. However, during this initial phase of life, trees that were dead at the time of sampling revealed that they had had a lower growth potential than healthy trees (Tab. I and Fig. 1). This can support the suggestion that resistance of individual trees to dieback decreases with the weakening of their growth potential or vigor. It is also in line with the observation that top-drying is more frequent in trees of average or below average size (Dobrowolska et al., 2008).

In the group of dead trees, after achieving maximal radial growth, the decrease of annual ring-growth increment was not only less abrupt but, temporarily, the increments were even wider than in healthier trees, which stands in some contradiction to the above statement. However, when the cumulative breast height diameter was calculated (not shown), the dead trees showed significantly (at $P=0.05$ ) lower values of this parameter over their lifespan. Perhaps to compensate for their initially slow growth, a much more potent increase of ring width afterwards is required. Due to lower breast height diameter the biomass production of dead trees appears to have been lowered. However, it was not possible to dissect the age- and allometry-related contributions to ring width decreases from that induced by $\mathrm{AD}$, as in all trees, healthy or not, this decrease was observed over the time when $\mathrm{AD}$ symptoms were manifested.

The radial pattern of changes in the diameters of earlywood vessel in ash trees investigated in this study (Fig. 4A) in general follows the sigmoidal curve reported for Fraxinus excelsior (Helińska-Raczkowska and Fabisiak, 1999) and other ring-porous species. Our data are consistent with the above authors' findings that the diameter of early vessel increases along with the cambial age of the respective annual growth rings up to approximately the 20th to 30th growth ring (Fig. 4), whereas the frequency of occurrence (density) of early vessels decreases (Fig. 3). However, we observed versatile tendencies among investigated groups of trees, especially during the last five years of life when symptoms of AD occurred in some of the trees. Dead and weakened trees show a decreased vessels diameter (Figs. 4A, 4B) and vessels density during last five 
years of their life, whereas healthy trees showed an increased vessels diameter and only a moderately lowered vessels density. Most striking is the opposing response of healthy and weakened trees during the final $5 \mathrm{y}$ before sampling, which shows that external factors may have been intervening to affect vessel formation. Whether these factors act selectively or are common to all the population growing in the same conditions, but trigger the decline process only in more vulnerable trees due to a lower capacity to adapt to a changing environment, remains to be elucidated. However, the adaptation mechanisms in trees relay mainly on growth responses. According to Tyree's hypothesis (2003), the prerequisite for maintaining high growth rates is high conductance. Thus, negative changes in hydraulically important structural parameters of wood in weakened and dead trees could be responsible for $\mathrm{AD}$ intensification.

In our studies, we observed a tendency for the new increments of secondary xylem of ash trees to increase in theoretical hydraulic conductivity. The highest conductivity was noted for healthy trees (Fig. 5). This is probably related to a genetically determined predisposition to produce wider earlywood vessels elements (Zobel and Buijtenen, 1989) that are efficient water conductors (Carlquist, 1975; Zimmermann, 1983). However, in healthy ash trees we observed a tendency to limit hydraulic conductivity after the 20th year of age. This could be justified as the time needed to adapt the life processes of the young tree to a changing environment. Trees have to adapt to environmental stress conditions, which influence the expression of their potential for growth (Drew et al. 2009) and reproduction. After the 20th year, healthy ashes again showed a tendency to increase their hydraulic conductivity. It seems they were able to re-configure their metabolic processes to new conditions of environment.

Weakened and dead ashes had smaller vessels thus potentially were less efficient in the transport of water when compared to the healthy group (Fig. 5). This is probably a result of individual variability existing within the species in relation to their allometry. It is known that the AD process is a result of multiple and cumulative causes. One of them is crown defoliation (observed in weakened and dead trees, Tab. I) causing photosynthetic reduction and resulting in a reduced stem diameter increment or/and the tree's conductive ability (Zimermmann, 1983). The next reason could be the formation of gas bubbles in xylem blocking water transport and leading to shoot dieback (Cochard et al., 1992). Embolism formation, which reduces stem hydraulic conductivity, seems be crucial for plants under drought stress. Utsumi et al. (1996; 1999) provided information that if cavitation occurs in the earlywood of ring-porous trees, then the latewood vessels, having smaller diameters and being less vulnerable to embolisation (Sperry and Sullivan, 1992; Tyree and Cochard, 1996), should contribute to the water transport system. Thus, latewood vessels formed in the previous season might play a major role in water transport at the onset of the growth in early spring when newly created earlywood vessels are not yet functional. Based on these results, it is suggested that in the dead ashes, latewood could not sufficiently contribute to the water transport restoration after the embolisation. The reduction of the latewood vessel zone observed in the case of the dead ashes (Fig. 2) is in line with that proposal. Because the survival of plants depends on the capacity to develop plastic responses to the ever-changing environment, it seems that the dead trees did not possess enough potential to adapt to stresses experienced in their environment.

In conclusion, our data provide evidence that vessel diameter, and in consequence the hydraulic conductivity, correlates with the degree of $\mathrm{AD}$ damage. More prone to decline are trees producing smaller earlywood vessels which in combination with density not higher than that of healthy trees, results in a substantial negative effect on hydraulic conductivity. The ring-width reduction consisting in a diminishing of the latewood zone has little impact on the hydraulic conductivity as, according to the Hagen-Poiseuille's law, the latter relays on the radii of the conducting capillaries. Therefore, it seems that the size of vessels, elements responsible for water transport in whole tree, is a crucial feature that should be taken into consideration in dendro-eco-physiological studies designed to unravel the issue of ash-tree decline.

Acknowledgements: This work was supported by The Ministry of Science and Higher Education within Rector of WULS-SGGW grant-in-aid No. 504-10-03080011. We thank Professor Stefan Zajązkowski from Department of Forest Botany at Warsaw University of Life Sciences - SGGW for helpful comments and Professor Peter Barlow, Bristol University, UK, for language revision and valuable comments on the manuscript.

\section{REFERENCES}

Atkinson C.J. and Denne M.P., 1988. Reactivation of vessel production in ash (Fraxinus excelsior L.) trees. Ann. Bot. 61: 679-688.

Bricker J.S. and Stutz J.C., 2004. Phytoplasmas associated with ash decline. J. Arboric. 30: 193-199.

Carlquist S., 1975. Ecological strategies of xylem evolution, University of California Press, Berkeley, 259 p.

Cochard H., Cruiziat P., and Tyree M.T., 1992. Use of positive pressures to establish vulnerability curves: further support of the air seeding hypothesis and implications for pressure - volume analysis. Plant Physiol. 100: 205-209.

Cochard H., PeifferM., Le Gall K., and Granier A., 1997. Developmental control of xylem hydraulic resistances and vulnerability to embolism in Fraxinus excelsior L.: Impacts of water relations. J. Exp. Bot. 48: 655-663.

Dobrowolska D., Hein S., Oosterbaan A., Skovsgaard J.P., and Wagner S.P., 2008. Ecology and growth of European ash (Fraxinus excelsior L.), http://www.valbro.uni-freiburg.de/, $35 \mathrm{p}$.

Drew D., Downem G., O’Grady A., Read J., and Worledge D., 2009. High resolution temporal variation in wood properties in irrigated and non - irrigated Eucalyptus globulus. Ann. For. Sci. 66: 406.

Helińska-Raczkowska L. and Fabisiak E., 1999. Radial variation of vessel lumen diameter as an indicator of the juvenile growth period in ash (Fraxinus excelsior L.). Holz Roh- Werkst. 57: 283-286.

Jacquiot C., Trenard Y., and Dirol D., 1973. Atlas d'anatomie des bois des Angiospermes, Vol. 1, Centre Technique du Bois, Paris, 175 p.

Kowalski T., 2007. Chalara fraxinea - nowo opisany gatunek grzyba na zamierajaych jesionach w Polsce. Sylwan 4: 44-48.

Kowalski T. and Łukomska A., 2005. Badania nad zamieraniem jesionu (Fraxinus excelsior L.) w drzewostanach Nadleśnictwa Włoszczowa. Acta Agrob. 58: 429-440. 
Köcher P., Gebauer T., Horna V., and Leuschner C., 2009. Leaf water status and stem xylem flux in relation to soil drought in five temperature broad-leaved tree species with contrasting water use strategies. Ann. For. Sci. 66: 101.

Larson P.R., 1994. The vascular cambium. Development and structure, Series Wood Science, Timell T.E. (Ed.). Springer-Verlag, Berlin, $725 \mathrm{p}$.

Larson P.R., Kretschman D.E., Clark A. III, and Isebrands J.G., 2001 Formation and properties of juvenile wood in southern pines: a synopsis. Gen. Tech. Rep. FPL-GTR-129, WI: US Department of Agriculture, Forest Service, Forest Product Laboratory, Madison, $42 \mathrm{p}$.

Lygis V., Vasiliauskas R., and Stenlid J., 2005. Pathological evaluation of declining Fraxinus excelsior stands of northern Lithuania, with particular reference to population of Armilliaria cepistipes. Scand. J. For. Res. 20: 337-346.

Margio G., Peltier J.P., and Girel J., 2000. Success in the demographic expansion of Fraxinus excelsior L. Trees 15: 1-13.

Roberts L.W., Gahan P.B., and Aloni R., 1988. Vascular differentiation and plant growth regulators, Series Wood Science, Timell T.E. (Ed.), Springer-Verlag, Berlin, $154 \mathrm{p}$.

Sperry J.S. and Sullivan E.M., 1992. Xylem embolism in response to freeze-thaw cycles and water stress in ring-porous, diffuse-porous, and conifer species. Plant Physiol. 100: 605-613.

Sperry J.S., Nichols K.L., Sullivan J.E.M., and Eastlack S.E., 1994. Xylem embolism in ring porous, diffuse-porous, and coniferous trees of northern Utah and interior Alaska. Ecology 75: 1736-1752.

Tyree M.T., 2003. Hydraulic limits on tree performance: transpiration, carbon gain and growth of tress. Trees 17: 95-100.

Tyree M.T. and Cochard H., 1996. Summer and winter embolism in oak: impact on water relations. Ann. Sci. For. 53:173-180.

Tyree M. and Zimmermann M.H., 2002. Xylem structure and the ascent of sap, Series Wood Science, Timell T.E. (Ed.), Springer-Verlag, Berlin, 283 p.
Utsumi Y., Sano Y., Ohtani J., and Fujikawa S., 1996. Seasonal changes in the distribution of water in the outer growth ring of Fraxinus mandshurica var. japonica: a study by cryo-scanning electron microscopy. IAWA J. 17: 113-124.

Utsumi Y., Sano Y., Funada R., Fujikawa S., and Ohtani J., 1999. The progression of cavitation in earlywood vessels of Fraxinus mandshurica var japonica during freezing and thawing. Plant Physiol. 121: 897-904.

Ward K., Ostry M., Venette R., Palik B., Hansen M., and Hatfield M., 2007. Assessment of Black Ash (Fraxinus nigra) decline in Minnesota. In: Proc. of the Eight Annual Forest Inventory and Analysis Symposium (in press)

Zajączkowski S., Wodzicki T.J., and Romberger J.A., 1984. Auxin waves and plant morphogenesis. In: Scott T.K. (Ed.), Hormonal regulation of development II, The functions of hormones from the level of the cell to the whole plant, Encyclopedia Plant Physiol., vol. 10, Springer-Verlag, Berlin, pp. 244-262.

Zajączkowski S., 1996. Changes in cambial activity and secondary xylem structure of Pinus sylvestris L. associated with ageing. In: Paschalis P., Zajączkowski S. (Eds.), Biodiversity protection of Białowieża Primeval Forest, Fundacja Rozwój SGGW, Warszawa, pp. 7-21.

Zimmermann M.H., 1963. How sap moves in trees, Freeman and Co., California, Sci. American, 10 p.

Zimmermann M.H., 1983. Xylem structure and the ascent of sap, Springer-Verlag, Berlin, $143 \mathrm{p}$.

Zimmermann M.H. and Brown C., 1977. Trees: structure and function, Springer-Verlag, New York, $336 \mathrm{p}$.

Zobel B.J. and Van Biujtenen J.P., 1989. Wood variation: its causes and control, Springer-Verlag, Berlin, 363 p.

Zobel B.J. and Sprague J.R., 1998. Juvenile wood in forest trees, Springer-Verlag, Berlin, $300 \mathrm{p}$. 